\title{
EVALUATING READING SYLLABUS OF ISLAMIC UNIVERSITY THROUGH CURRICULUM IDEOLOGY
}

\author{
Fikrunnisa Sahlan', Gunawan Mansur' ${ }^{2}$, Ahmed Djoumoi ${ }^{3}$ \\ 1,2,3 Universitas Negeri Malang \\ 1,2,3Jl. Semarang 5, Malang, East Java, 65145 \\ Email: fikrunnisahlan93@yahoo.com ${ }^{1}$, gunawanmansur2004@gmail.com², \\ ahmedcomoros@gmail.com ${ }^{3}$
}

\begin{abstract}
:
This study aimed to evaluate the syllabus from English Language Teaching (ELT) Department of an Islamic university in order to find out the integration of curriculum ideology. Reading II which one of the courses in ELT department of Universitas Islam Malang (Unisma) was used as the object to conduct this study. Interview, documents, evaluation checklist, and guideline to evaluate the integration of curriculum ideology were used as research instrument. The result showed that Reading II course syllabus from ELT department in undergraduate program of Unisma did not include all components of syllabus. Moreover, ELT Department of Unisma was already precise in order to curriculum development process. However, the syllabus as a feature to reflect the curriculum ideology did not clearly show the integration of the vision and the missions of ELT department which were based on Islamic characteristics, entrepreneurship, and ICT-based learning.
\end{abstract}

\begin{abstract}
Abstrak:
Penelitian ini bertujuan untuk mengevaluasi silabus Program Studi Pendidikan Bahasa Inggris di sebuah universitas Islam untuk menemukan pengintegrasian ideologi kurikulum. Reading II yang merupakan salah satu mata kuliah dalam Program Studi Pendidikan Bahasa Inggris di Universitas Islam Malang (Unisma) digunakan sebagai sampel untuk melakukan penelitian ini. Wawancara, dokumen-dokumen, daftar evaluasi, dan panduan untuk mengevaluasi pengintegrasian ideologi kurikulum digunakan sebagai instrumen penelitian. Hasil penelitian menunjukkan bahwa silabus mata kuliah Reading II di Program Studi S1 Pendidikan Bahasa Inggris di Unisma belum memasukan seluruh komponen silabus. Selanjutnya, Program Studi Pendidikan Bahasa Inggris Unisma sudah tepat dalam proses pengembangan kurikulum. Tetapi, silabus sebagai sarana perwujudan ideologi kurikulum tidak menunjukkan secara jelas adanya pengintegrasian visi dan misi Program Studi Pendidikan Bahasa Inggris yang berdasar pada karakter Islam, kewiraswastaan, dan pembelajaran berbasis ICT.
\end{abstract}

\section{Keywords:}

Islamic University, Curriculum Ideology, ELT Department, Reading Syllabus, Syllabus Evaluation

INDONESIA as a country which majority of the population is Muslim, the society is familiar with Islam based schools. Spread of Islamic university is also a reality that happens in Indonesia. Like any university, Islamic universities today provide variance department not only focus on religious education but also general education 
(Hashim \& Langgulung, 2008). Therefore, Islamic universities in Indonesia reflect Islam education that deal with modern society.

Moreover, based on the Law of the Republic of Indonesia Number 20 Year 2003 on National Education System at Article 30 Section 2, government of Indonesia defines function of religious education to educate students to be the member of society that in line with their religion (Republik Indonesia, 2003). This law confirms that Islamic university can organize education to integrate with Islamic values. Nata (2016) explains that Islam education is created by religious base, philosophy base, and knowledge base. This is the uniqueness of Islam education than public education. Curriculum of Islam education will be able to harmonize Islam values even in condition to learn general study.

Curriculum and syllabus are two different things but have great connection (Nunan, 1988; Richards, 2001). Curriculum focuses on organizing the institution to achieve educational target. However, syllabus deals with the formulation of teaching and learning process for certain course. In other words, syllabus is curriculum's component in order to achieve the successes in education.

This study was interested to evaluate syllabus of modern education by considering the curriculum ideology of Islamic university. English Language Teaching (ELT) department is one example of modern education that expansively serves in Islamic institution. As a department which focus on learning the universal language, it can deal with ICT learning and contextual learning. This shows that ELT syllabus will be flexible even to integrate into curriculum in Islamic university. Thus, this study intends to describe and analyse ELT Department syllabus of an Islamic university in order to find out how the integration of curriculum ideology.

\section{RESEARCH METHODOLOGY}

The design of this study is evaluation research. (Gall, Gall, \& Borg, 2003) explain that evaluation research deals with discovering the performance of educational setting. It is more related to the management of the education program. Therefore, evaluation research is proper to encounter the purpose of this study.

This study takes place in ELT Department of Unisma which is located in Malang, East Java, Indonesia. The purposes of this study are to evaluate the component of syllabus and to find out the integration of curriculum ideology in the syllabus. Therefore, this study employed some instruments which were (1) interview, (2) document such as syllabus, vision and mission of the university and the department, (3) evaluation checklist which is developed based on communicative syllabus of Brown dan Lee (2015), and (4) guideline to evaluate integration of curriculum which is based on a sound curriculum by Richards (2001).

In the first step, this study interviewed the leadership team of the department. Interview process involved the Third vice Dean of Teacher Training and Education Faculty of Unisma and the coordinator of ELT Department in undergraduate program of Unisma. Interview was held in order to collect information about the process of 
curriculum changing and the process of designing the syllabus in ELT Department. After the interview, the coordinator of ELT Department then provided the researchers access to use Reading II course syllabus to be evaluated. After getting the document, this study then focused on evaluating component of Reading II course syllabus by using the evaluation checklist. As a final point, this study evaluated the integration of curriculum ideology by using the result of interview, document, and guideline by Richards (2001).

\section{FINDING AND DISCUSSION}

Unisma is one example of Islamic university. It points on Ahlus Sunnah Wal Jama'ah which means that obedient to Al-Qur'an and authentic Hadith. This character then is integrated to the vision and mission of Unisma in all departments including English Language Teaching (ELT) department.

ELT department as one the department in Unisma which has vision as "to embody ELT department which is excellent and competitive, has entrepreneurship insight based on Ahlus Sunnah Wal Jama'ah of Islam character in 2020". Furthermore, the missions of department is constructed into four points which are (1) operating high quality education in the field of ELT in order to train English teachers that are professional, competitive, and relevant to the needs of society (stakeholders) as well as the global development of education that characterize on Ahlus Sunnah Wal Jamaah of Islam, (2) conducting research in the field of ELT in interdisciplinary to enhance the quality of ELT as well as resolve the problem of ELT in Indonesia, (3) conducting and improving community service that oriented to enhance teachers' professionalism and beneficial to people's benefit, and (4) operating cooperation with various parties both national and international in the implementation of Tri Dharma Perguruan Tinggi (Three Obligations of Higher Education) to support academic and functional culture for academic civitas of ELT Unisma and society. The statements of vision and mission are considered as the goals of the university which will reflect the ideology of Unisma curriculum especially curriculum of ELT department.

The results of the interviews expose that there are two kinds of process of curriculum changing in Unisma. First, accidental changing means that the curriculum will changes because of the university or the department is involved in a project that needs to change their curriculum. For example, the department gets grant for the revitalization of their curriculum. However, it only impacts on the students from the academic year where that program was held. Second, periodic changing is held for biennial or quadrennial. It depends on the needs of the department. Both changes consider about government regulations, the evaluation result of PPL/KKN (Social Action Internship) process especially inputs from the cooperation schools, the input from alumni who work in education field, and internal of department in order to formulate the new curriculum. Both curriculum changes will impact on the content of the syllabus.

Therefore, when the department changes or modifies the curriculum 
automatically they rebuild their syllabus. In order to do that, it will be discussed and arranged together in department meeting. The purpose of the change focuses on making the new curriculum to be suitable with the needs, the vision, and the missions of the department. Thus, the course syllabus of Unisma now should integrate the characteristics of Ahlus Sunnah Wal Jama'ah, ICT-based learning, and edupreneurship.

From the process of evaluation, the researchers found that the syllabus is textbased syllabus which is integrated to competency-based syllabus. It is because it employs various types of text and all the indicators need the students to achieve some abilities such as explaining and applying reading strategies, identifying topics and main ideas, identifying detailed information, differentiating and comprehending various text types. Richards (2001: 163) has explained that "text-based syllabus is built around texts and samples of extended discourse". It is also a type of integrated syllabus. That is why the syllabus integrate competency-based syllabus.

Unisma used the term Rencana Pembelajaran Semester (RPS) or Semester Plan instead of course syllabus. In the beginning of the syllabus, it informs us about the identity of the course which includes the Unisma logo, RPS term, course name and code, name of department, name of faculty, name of university, the semester, credits, and the name of lecturer. Next, it shows list of educational goals and course goals. After that, there is a table which is consisted of columns of weeks, course objectives, indicators and assessment criteria, learning materials, learning methods, students' learning activities, and weighting. In the end of the syllabus, there are list of references and the place for signature of the authoritative.

This syllabus is the new one to be applied in teaching Reading II course in Unisma. It was made in 28 November 2016. Reading II course is in the second semester and has four credits. Based on the explanation from the interview process, in the new curriculum change, Vocabulary I and Vocabulary II courses were deleted then they are integrated to Reading I and Reading II courses. That is why Reading I and II courses have four credits but Reading III course only two credits.

The syllabus is written by using Indonesian language and English. Indonesian language is used in the cover, course description, and the head of syllabus table. English then is used to state the course goals, the content of syllabus table, and references. It will be better if the syllabus use only one language especially English in order to make it consistent, relevant and structured.

\section{Components of Reading II Syllabus}

The intention of the study is to evaluate Reading II syllabus of ELT department in order to figure out the appearance of Islamic university syllabus. According to Brown dan Lee (2015), there are eight components of communicative syllabus which are goals of course, suggested objective, sequential list of functions (purposes), sequential list of topics and situations matched to the functions, sequential list of grammatical, lexical and/or phonological forms to be taught, sequential list of skills, references, and suggestion for doing assessment. These components are basic to design a language syllabus. Thus, teacher or lecturer should input the all components. 
Furthermore, there are some issues that must be considered when talking about teaching reading. First, the process of reading methodology is applied bottom-up or top-down processing. Second, consider about the use of readers' schemata theory and background knowledge. Third, teach the strategic reading to the students. Fourth, serve extensive reading activity. Fifth, aim to reading rate, fluency, and automaticity. Sixth, focus on teaching vocabulary. Seventh, apply affective and culture factors. Last, the teaching focuses on second language literacy (Brown \& Lee, 2015).

Brown dan Lee (2015) explain that communicative syllabus must describe the course goals, objectives, list of functions, list of topics, list of language components, list of skills, references, also the assessment. However, this syllabus does not cover all the components of syllabus. It does not have description of course, list of topics, list of media to be used, and possible suggestions of assessment for each week. There is no any information in weighting column. Moreover, the references are so limited which only included two books and supplementary materials from the lecturer for all semester. It is not clear if the references will be used for all weeks or each reference have different period to be employed in the teaching process. Meanwhile, references in reading course are crucial aspect. Riswanto dan Febriani (2016) explain that reading materials are sensitive for students and teacher should provide attractive reading materials. Thus, Reading II syllabus should be reorganized in order to fulfil the basic component of communicative syllabus.

Based on the result of evaluation checklist, Reading II syllabus already includes some components of communicative syllabus. First, the goals and objectives of the course already stated in Reading II syllabus. The course goals are written as Capaian Pembelajaran $M K(C P-M K)$ and the objectives are written as Kemampuan Akhir yang Diharapkan (Sub CP-MK) of the syllabus. The goals are (1) students can explain and apply reading strategies to comprehend the text; (2) students can identify the topic and main idea of various texts; (3) students can identify the detailed information of various texts; and (4) students can differentiate and comprehend various text types. The objectives are (1) students are able to explain and apply reading skills and strategies to comprehend English texts; (2) students are able to find the topic and main idea of the passage and the main idea of each paragraph; (3) students are able to identify the detailed information of the text; (4) students are able to identify the characteristics and comprehend narrative texts; (5) students are able to identify the characteristics and comprehend report texts; (6) students are able to identify the characteristics and comprehend expository texts; (7) students are able to identify the characteristics and comprehend argumentative essays; (8) students are able to identify the characteristics and comprehend comparison and contrast essays. It covers both reading comprehension and skill.

However, the statements of goals and objectives are not precise yet. The statements are mostly too general and similar each other. As a result, it seems like repetition of the goals by using different words. According to Moore (2005), educational goal and objective are different because goal is nonobservable statement 
meanwhile objective is observable. Words such as explain, apply, and identify are considered as observable verb so they are unsuitable to be used in goal statement. It also happen in the objective statement for the using of comprehend word. Still, the objectives statement explains the variation of genre texts which are narrative text, report text, expository text, and argumentative essay as detail of the goal statement.

Time management for each material seems not suitable. Gonzales (2010) supports that time management is important to serve good English learning. In this case, the syllabus divides the materials through 16 weeks teaching which each material will be teach in two weeks. Meanwhile, this course has 4 credits. It means that to teach one topic, it needs four meetings or eight hours. For instance, the material of narrative text that focuses on identifying and comprehension in narrative text taught four two weeks. Thus, it needs to reduce time allocation for each topic.

The strategies that are proposed in this syllabus are not attractive and varied. Brown dan Lee (2015) already proposed some strategies for reading comprehension which are (1) identify the purpose in reading, (2) use graphemic rules and patterns to aid in bottom-up decoding, (3) use efficient silent reading techniques for improving fluency, (4) skim the text for main ideas, (5) scan the text for specific information, (6) use semantic mapping or clustering, (7) guess when you are not certain, (8) analyse vocabulary, (9) distinguishing between literal and implied meanings, and (10) capitalize on discourse markers to process relationships. However, the syllabus only focuses to skimming and scanning for reading various text types. The first six weeks, the syllabus employs lecturing as the method. It is more teacher-centered approach.

\section{Integration of The Curriculum Ideology}

In order to find out the integration of curriculum ideology especially in Reading II syllabus of Unisma, this study involves information that is collected through interview and document. The data then analyse by using guideline of a sound curriculum of Richards (2001). The result shows that ELT Department of Unisma already serves course series in order to meet the need of students. ELT Department of Unisma includes Islamic courses (Agama Islam I-VI), ICT-Based Learning course, and entrepreneurship course besides courses that are related to ELT. The list of courses in the curriculum proves that ELT Department of Unisma tries to achieve the vision and mission of the ELT Department of Unisma which is based on Islamic characteristics, ICT-Based, and entrepreneurship. Ansyari (2015) explains that English and ICT have good relation in learning process. The curriculum ideology of Unisma shows that positive concept in order to maintain ELT Department.

From the result of interview, ELT department of Unisma already perform the process of need analysis and situational analysis in order to curriculum development. The department always evaluates the result of students' performance especially from $P K L / K K N$ or social internship activity. The department is also opened for the input from the cooperation schools, alumni, and internal department in order to be deal with the need of students, institution, and society.

On the other hand, the syllabus in this department still does not fulfil the 
precise form of communicative syllabus. As component of curriculum, syllabus have important role to reflect the curriculum ideology. Curriculum ideology is concept of the education institution that covers all members of the institution necessity (Richards, 2001).

From the interview and looking to the vision and mission of the ELT Department of Unisma, it is stated that ELT Department of Unisma wants to integrate Islam character, edupreneurship, and ICT-based in the process of learning as the curriculum ideology. However, Reading II course syllabus does not clearly reflect the curriculum ideology. Yusnita (2015) clarifies that developing syllabus should refers to curriculum. After analyse the syllabus, the appearance likes general reading syllabus. For instance, list of learning activities in the syllabus does not explain when and how the integration of ICT learning in the process of teaching and learning. The learning method which consists of lecturing, group discussion, and cooperative learning does not reflect learning process which is based on edupreneurship. Edupreneurship is combination of educator professionalism and business attractiveness (Petterson, 2018). Learning sources are which are explained in syllabus references did not support learning that integrate Islamic character. To sum up, Reading II syllabus did not precisely reflect the integration of Islam characteristics, edupreneurship, and ICTbased. The reason of this result is from the component of the Reading II syllabus itself still incomplete. Thus, the syllabus should accomplish all basic component of communicative syllabus.

\section{CONCLUSION}

In order to conclude this study, researchers divide it into two points. First, Reading II syllabus of Unisma does not meet all components of syllabus yet. A syllabus needs to include all components of syllabus especially for the assessment. Second, ELT Department of Unisma properly serves courses in order to deals with curriculum ideology which are based on Islam characteristics, entrepreneurship, and ICT-based learning. However, the syllabus as one feature to reflect the curriculum does not completely describe the integration of curriculum ideology. Thus, it can be as suggestion for ELT Department of Unisma in order to reorganize their syllabus content.

For further researcher, it is better to conduct a research in order to find out the implementation of the syllabus. The syllabus did not show the integration of ideology curriculum of Unisma yet, but it may be integrated into the process of teaching and learning. So, it needs more future researcher to investigate this issue.

\section{BIBLIOGRAPHY}

Ansyari, M. F. (2015). A Conceptual Model of Islamic Integrated Curriculum Development for Pre-service English Teacher Program at One Indonesian Islamic Public University. In Epistemology and Methodology for A New Paradigm 
of Human Sciences in Islamic Perspective. Jakarta: Sadra Press, Sadra International Institute. Retrieved from https://www.researchgate.net/profile/Muhammad_Ansyari/publication/29 9823683_IC_THuSI_Proceeding/links/5705e23708ae44d70ee348d7/IC-THuSIProceeding.pdf?origin=publication_detail

Brown, H. D., \& Lee, H. (2015). Teaching by Principles: An Interactive Approach to Language Pedagogy. USA: Pearson Education, Inc.

Gall, M., Gall, J. P., \& Borg, W. R. (2003). Education Research, An Introduction. USA: Pearson Education, Inc.

Gonzales, E. F. (2010). Evaluating A Communicative Syllabus in A Mexican EFL Context. Retrieved from https://www.birmingham.ac.uk/Documents/collegeartslaw/cels/essays/sylabusandmaterials/SMElsaFernandaGonzalez.pdf

Hashim, C. N., \& Langgulung, H. (2008). Islamic Religious Curriculum in Muslim Countries: The Experiences of Indonesia and Malaysia. Bulletin of Education $\mathcal{E}$ Research, 30(1), 1-19. Retrieved from http://pu.edu.pk/images/journal/ier/currentissue_pdf/5_Che Noraini Article_BER.pdf

Moore, K. D. (2005). Effective Instructional Strategies: from Theory to Practice. United States of America: Sage Publications, Inc.

Nata, A. (2016). Ilmu Pendidikan Islam. Jakarta: Prenada Media.

Nunan, D. (1988). Syllabus Design. Oxford: Oxford University Press.

Petterson, C. (2018). 5 Questions on Edupreneurship and Reasons Why It's Perfect for You. Retrieved from https://elearningindustry.com/edupreneurshipquestions-reasons-perfect.

Republik Indonesia. Undang-Undang RI Nomor 20 Tahun 2003 tentang Sistem Pendidikan Nasional (2003). Jakarta: Sekretariat Negara.

Richards, J. C. (2001). Curriculum Development in Language Teaching. USA: Cambridge University Press.

Riswanto, \& Febriani, H. (2016). Supplementary Reading Materials for Madrasah Learners Based on Genre Approach. Jurnal Pendidikan Islam, 2(3), 459-474. Retrieved from http://journal.uinsgd.ac.id/index.php/jpi/article/view/779

Yusnita, D. (2015). Designing Reading Materials for The Faculty of Social and Political Sciences at UIN Syarif Hidayatullah Jakarta. Indonesian Journal of English Education, 2(1), 28-45. Retrieved from http://journal.uinjkt.ac.id/index.php/ijee/article/view/2002 